\title{
Studi penguasaan Matematika dan Bahasa Inggris anak asuh Yayasan Al-Kamilah, Depok, Jawa Barat
}

\author{
Angga Hidayat ${ }^{*}$; Yuliana Friska ${ }^{1}$; Anita Anggraini ${ }^{1}$; Moh. Thoyib Syafi'i'; Ani Kusumaningsih ${ }^{1}$ \\ ${ }^{1}$ Program studi S1 Akuntansi, Fakultas Ekonomi, Universitas Pamulang \\ e-mail: angga1203hidayat@gmail.com; yulianafriska87@yahoo.com; dosen01262@unpam.ac.id; \\ mohthoyibsyafii@gmail.com; anikoesoema@gmail.com
}

\begin{abstract}
Abstrak. Fenomena yang dihadapi oleh siswa-siswi yang menetap di yayasan Al-Kamilah adalah kurangnya kemampuan dalam berbahasa Inggris dan kurangnya kemampuan berhitung matematika dasar. Padahal hal tersebut merupakan kemampuan dasar yang sangat diperlukan dalam kehidupan sehari-hari, terlebih dalam menunjang keberhasilan seseorang dalam berkarir maupun berwirausaha. Oleh karena itu, dalam Pengabdian Kepada Masyarakat (PKM) ini, kembali kami membimbing siswa-siswi di Yayasan Al-Kamilah, Depok, Jawa Barat. Program ini berlangsug selama 1 bulan, melanjutkan program kami yang sebelumnya sehingga terjadi kesinambungan. Dengan demikian manfaat yang diperoleh akan terlihat nyata dan dapat diimplementasikan langsung, dibanding hanya mengunjungi selama beberapa hari. Metode Pelaksanaan yang digunakan dalam melakukan kegiatan ini terdiri dari 2 tahapan yaitu: penyusunan materi ajar dan proses belajar (disertai pendampingan). Materi disusun sedemikian hingga mudah dipahami dan dipraktekkan, dengan cara memperbanyak conversation (untuk Bahasa Inggris) dan matematika terapan (untuk Matematika) dikaitkan dengan daily activity. Sedangkan pemberian materi pelatihan akan dilakukan oleh para dosen Universitas Pamulang yang sudah berpengalaman mengajar matematika dan Bahasa Inggris, tidak hanya di kampus saja tetapi juga di berbagai instansi bergengsi lainnya. Selain itu, penentuan narasumber juga didasarkan dari latar belakang setiap pengajar yang dapat memberikan materi ajar dengan cara yang menyenangkan sehingga mudah dipahami oleh para peserta pelatihan. Harapannya, peserta dapat menangkap konsep-konsep dasar matematika dan menerapkan keterampilan berbicara Bahasa Inggris dalam kehidupan sehari-hari.
\end{abstract}

Kata kunci: Matematika; Bahasa Inggris; Studi Penguasaan

\begin{abstract}
The phenomenon faced by students who lived at Al-Kamilah foundation is a lack of ability in English and a lack of basic math skill. Though it is a basic ability that is needed in daily life, especially in supporting one's success in a career or entrepreneurship. Therefore, in this Community Service (PKM), we return to guide students at Al-Kamilah Foundation, Depok, West Java. This program lasts for 1 month, continuing our previous program so that there will be continuity. Moreover, the benefits obtained will be seen and can be implemented directly, rather than just visiting for a few days. The Implementation method conducted in carrying out this activity consists of 2 stages: the preparation of teaching materials and the learning process (accompanied by mentoring). The materials are arranged so that they will be easily understood and practiced, by conversations (for English) and applied mathematics (for Mathematics) associated with daily activity. While the training materials will be provided by Pamulang University lecturers who have experience teaching mathematics and English, not only at campus but also in various other prestigious agencies. In addition, the determination of speakers is also based on the background of each teacher who can provide teaching materials in a fun way so that they are easily understood by the trainees. It is hoped that the participants can grasp the basic concepts of mathematics and apply English speaking skills in their daily lives.
\end{abstract}

Keywords: Mathematic; English; Mastery Study 


\section{Pendahuluan}

Bahasa merupakan alat komunikasi yang penting bagi manusia. Melalui bahasa kita dapat mengetahui informasi yang kita butuhkan. Kita pun dapat menyampaikan ide dan gagasan kita melalui Bahasa (Pujiono, 2012).

Demikian juga dengan pembelajaran matematika dinilai sangat penting, mulai dari jenjang sekolah dasar sampai perguruan tinggi, karena matematika berfungsi dalam mengembangkan daya nalar kemampuan berpikir (Kariadinata, 2012)

Oleh sebab itu, generasi penerus kita harus mampu menguasai bahasa dan matematika dengan baik. Terutama bahasa Inggris karena merupakan bahasa internasional. Apalagi di era milenial yang segala sesuatunya terkoneksi secara global dan serba online. Jika kita tidak menguasi bahasa Inggris maka akan tertinggal dengan negara lain. Pun, untuk matematika sangat diperlukan karena yang diambil adalah konsep berpikirnya yang sistematis dan logis (bukan sekedar belajar menghitung).

Salah satu lembaga yang perlu mendapat perhatian khusus dalam pengembangan bahasa Inggris dan matematika adalah Yayasan Al-Kamilah yang berlokasi di Jl. Serua Raya No 3, Serua, Kec. Bojongsari, Kota Depok, Jawa Barat 16517. Yayasan Al-Kamilah merupakan yayasan yatim piatu yang dirintis sejak tahun 2012. Yayasan ini awalnya berdiri di lahan seluas 200 meter persegi dengan cara mengangsur. Yayasan ini resmi terdaftar pada akta notaris Muhammad Ali, S.H., M.Kn. pada tanggal 13 Oktober 2012.

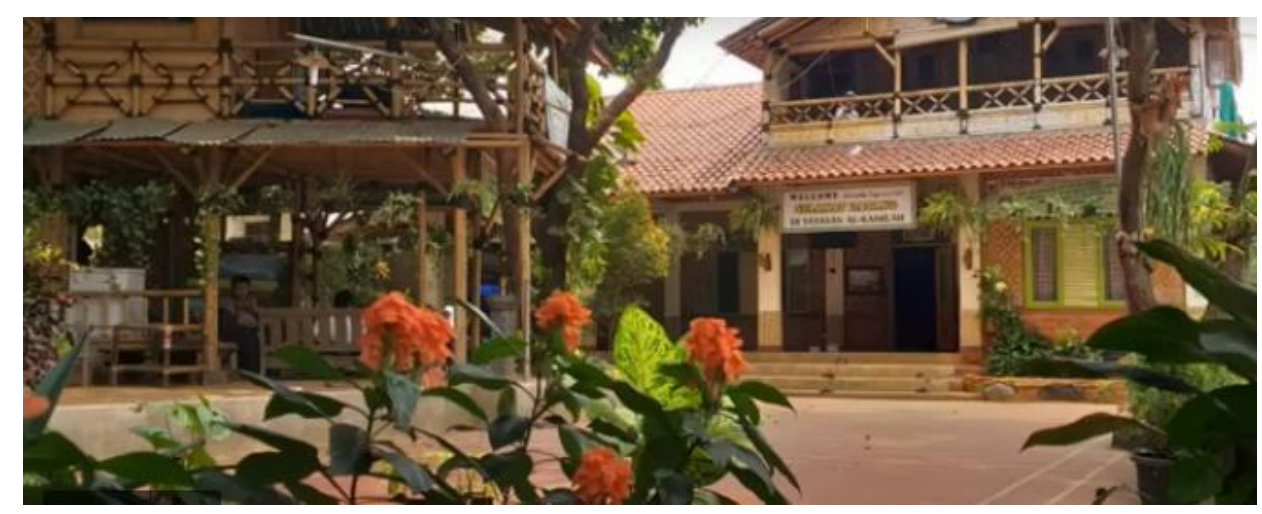

Gambar 1. Pondok Putri dan Saung Baca Yayasan Al-Kamilah

Seiring berjalannya waktu, yayasan Al-Kamilah dapat mendirikan bangunan yang digunakan untuk tempat tinggal anak-anak yatim piatu dan dhuafa pada April 2013. Anak yatim piatu dan dhuafa ini berasal dari berbagai daerah di Indonesia, di antaranya yaitu: Jakarta, Bogor, Depok, Tangerang, Bekasi, Bandung, Tasikmalaya, Lombok dan Flores. Keragaman siswa-siswi tersebut dapat tergambar sebagaimana dalam gambar 2.

Yayasan Al-Kamilah juga membantu pendidikan anak asuhnya dengan cara menyekolahkan mereka di sekolah-sekolah sekitar yayasan ini berada. Namun demikian, kebanyakan anak asuh AlKamilah memiliki kemampuan akademik di bawah standar anak yang sebaya dengan mereka, khususnya dalam mata pelajaran matematika dan Bahasa Inggris. Berdasarkan data pada saat survey pendahuluan di lapangan, didapati nilai kedua mata pelajaran tersebut di bawah rata-rata siswa seusianya.

Selain itu, kemampuan berbicara dalam Bahasa Inggris juga sangat penting dimiliki oleh siswa yang tinggal di yayasan tersebut. Hal ini dikarenakan status yayasan ini sebagai yayasan teladan tingkat nasional. Sehingga banyak pihak dari luar, terutama dari negara lain yang datang untuk 
melakukan studi banding mengenai pengelolaan yayasan. Oleh karena itu, siswa secara otomatis harus berinteraksi dengan orang asing yang berbicara dalam Bahasa Inggris.

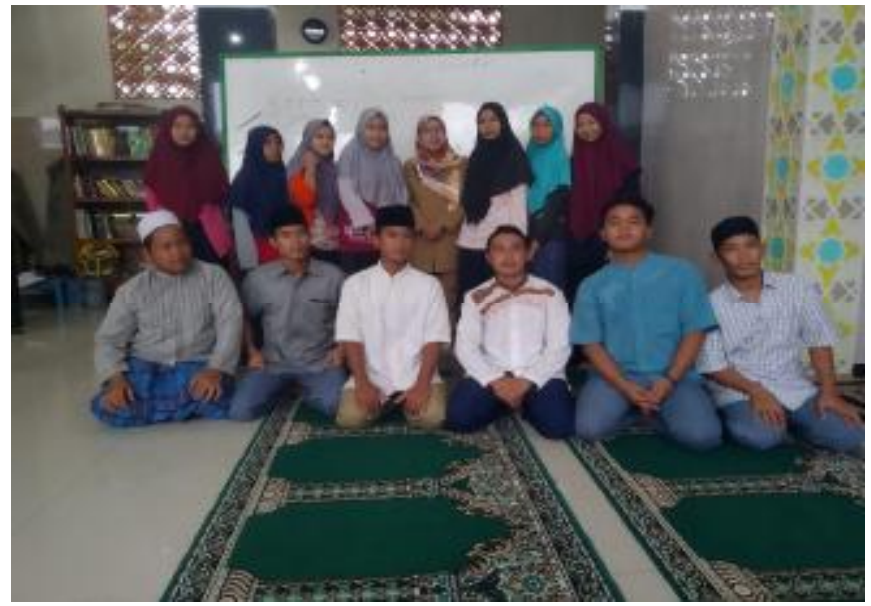

Gambar 2. Beberapa Anak Asuh Yayasan Al-Kamilah

Akan tetapi proses interaksi ini memiliki kendala dikarenakan siswa-siswi belum memiliki kemampuan yang memadai dalam berbicara dalam bahasa asing, terutama Bahasa Inggris. Sehingga kembali tim pengabdi memiliki inisiatif untuk melanjutkan pelatihan berbahasa inggris kepada siswasiswi yang tinggal menetap di yayasan (Hidayat et al., 2019). Hal lain yang perlu diperhatikan adalah pelatihan ini harus dilakukan secara kontinyu. Mengingat bahwa untuk memiliki kemampuan berbicara yang memadai diperlukan latihan terus-menerus (practice make perfect) sehingga diperlukan kebersinambungan pelatihan yang tidak hanya dilakukan dalam satu hari saja (Wahyuni, Indriastuti, \& Mustikawati, 2018).

Mata pelajaran yang perlu diperhatikan selain Bahasa Inggris agar kemampuan dalam menghadapi tantangan era revolusi digital adalah matematika (Abramovich, 2014). Matematika ini sangat penting dipelajari karena merupakan queen of science yang menjadi akar dari semua ilmu modern (Ku et al., 2014). Selain itu, fakta bahwa kemampuan berhitung dasar sekali pun dari siswa-siswi yang tinggal menetap di Yayasan Al-Kamilah masih lemah dan perlu ditingkatkan secara signifikan. Dan yang paling penting salah satu fungsi belajar matematika adalah tidak hanya sekedar berhitung tetapi untuk meningkatkan daya nalar mereka.

Tim pengabdi juga mengembangkan suatu metode yang tepat agar siswa-siswi Al-Kamilah dapat lebih memahami matematika, terutama dengan cara yang mudah dan menyenangkan. Hal ini perlu diperhatikan karena siswa-siswi di Al-Kamilah memiliki beragam latar belakang sosial sehingga akan berdampak kepada daya serap setiap siswa. Tim peneliti berupaya agar metode yang digunakan dapat membantu setiap siswa, tanpa terkecuali, terutama dalam memahami kebutuhan matematika setiap siswa.

Peningkatan kemampuan berbahasa Inggris dan matematika menjadi penting bagi setiap siswa, tidak terkecuali siswa-siswi yang menetap di Yayasan Al-Kamilah, agar tidak kalah cepat dengan arus dan pesatnya perkembangan teknologi dan globalisasi. Selain itu, kedua kemampuan ini juga menjadi modal utama untuk melanjutkan ke jenjang pendidikan yang lebih tinggi, khususnya jenjang perguruan tinggi.

Manfaat yang akan dirasakan dengan melanjutkan pendidikan ke jenjang yang lebih tinggi di antaranya adalah: 1) Memberikan perubahan taraf hidup yang lebih baik dan lebih berkualitas, dengan mudah dapat memperoleh pekerjaan yang lebih baik dan berpenghasilan tinggi; 2) Memiliki tingkat pergaulan yang lebih luas, baik di lingkungan kampus tempat kuliah maupun di luar kampus. Hal ini 
secara otomatis akan menambah relasi yang dapat memberikan keuntungan bagi masa depan mereka dalam berkarir; 3) Memiliki pengetahuan dan daya kreatifitas yang tinggi, sehingga mampu bersaing dengan dunia kerja dan bisnis di Indonesia, bahkan memiliki peluang sangat tinggi untuk berkarir di luar negeri; 4) Lebih dihargai di masyarakat dalam arti secara keilmuan, karena seseorang yang berpendidikan tinggi tentu mendapatkan pelajaran mengenai attitude dan etika yang baik dalam pergaulan; 5) Banyak perguruan tinggi yang memberikan syarat kemampuan bahasa Inggris dengan skor TOEFL 550, bahkan 600 (khusus jurusan Hubungan Internasional), sehingga perlu dibekali dengan dasar yang baik.

Kelima manfaat di atas merupakan modal yang penting untuk meraih masa depan yang gemilang demi bersaing menuju perkembangan teknologi yang sangat cepat, khususnya di era revolusi industri 4.0 saat ini. Bahkan, ke depannya yaitu menyongsong era revolusi industri 5.0 yang ditandai dengan internet of things. Segala sesuatu akan terhubung dengan internet (online) (Hidayat, 2019). Peranan matematika yang merupakan ratu ilmu pengetahuan akan membantu setiap mahasiswa baik dari jurusan apa pun yang diambil untuk memahami logic dari aplikasi penggunaan internet of things di masa depan (Hidayat \& Prasetya, 2020).

Selain itu, produk yang diciptakan dari hasil pesatnya teknologi akan menggunakan Bahasa Inggris sebagai bahasa yang tertulis dalam produk maupun panduannya (user manual), sehingga setiap mahasiswa baik dari jurusan apa pun yang diambil harus memahami Bahasa Inggris agar dapat mengoperasikan internet of things.

Selain itu, penggunaan internet of things yang menjadi dasar atas perkembangan teknologi era revolusi industri perlu diajarkan oleh tim pengabdi agar setiap anak asuh yayasan al-Kamilah dapat menghadapi era revolusi industri 5.0. Baru saja kita mendengar konsep revolusi industri 4.0 dengan memanfaatkan data, teknologi blockchain, serta kecerdasan buatan, namun Jepang justru sudah hadir dengan memperkenalkan konsep Society 5.0. Revolusi industri dengan konsep baru ini dinilai dapat menggantikan 4 versi sebelumnya yang hanya menitikberatkan pada produksi barang atau jasa.

\section{Metode}

Metode Pelaksanaan yang digunakan dalam melakukan kegiatan Pengabdian Kepada Masyarakat ini terdiri dari 2 tahapan, yaitu penyusunan Materi dan Proses Pelatihan.

Dalam menyusun materi pelatihan ada 2 hal yang menjadi dasar pertimbangan, yaitu kondisi siswa-siswi di Alkamilah dan apa yang menjadi kebutuhan mereka. Kondisi siswa-siswi di Alkamilah dari sisi pendidikan masih kurang jika dibandingkan dengan rerata anak seusianya. Berdasarkan hasil pengamatan dan wawancara pada saat pengabdian sebelumnya diperoleh data bahwa setelah diberikan pelatihan secara intensif terjadi peningkatan nilai mereka.

Terkait kebutuhan untuk pelatihan, bimbingan dan pendampingan yang didapat dari hasil pengamatan yang telah dibahas pada poin nomor 1, maka dapat diketahui kebutuhan yang diperlukan, yaitu, a) Pelatihan matematika sederhana; b) Pelatihan berbicara bahasa Inggris.

Proses pelatihan dalam Pengabdian Kepada Masyarakat ini adalah dengan memberikan pelatihan secara berkala kepada siswa-siswi yang menetap di yayasan Al-Kamilah. Pelatihan ini akan dilakukan secara berkala selama 1 bulan, yaitu dimulai dari tanggal 26 Februari 2020 dan diakhiri pada tanggal 26 Maret 2020. 
Pada awal pelatihan, yaitu saat pertemuan pertama disampaikan oleh Yuliana Friska, S.Pd., M.Pd. dengan materi Bahasa Inggris. Yuliana Friska memiliki latar belakang sarjana pendidikan Bahasa Inggris dari Universitas Islam Negeri Syarif Hidayatullah. Yuliana Friska menyampaikan materi pelatihan Bahasa Inggris tentang greeting dan bagaimana melakukan percakapan (conversation) sederhana jika bertemu dengan orang asing. Walaupun materi pelatihan merupakan materi yang sangat dasar, tetapi Yuliana Friska, S.Pd., M.Pd. menjadikan materi secara menarik sehingga setiap peserta pelatihan antusias dan langsung mempraktekkan materi pelatihan yang disajikan. Selain itu, Yuliana Friska, S.Pd., M.Pd. juga memberikan beberapa games dan kuis sehingga peserta tidak bosan dengan materi yang disiapkan.

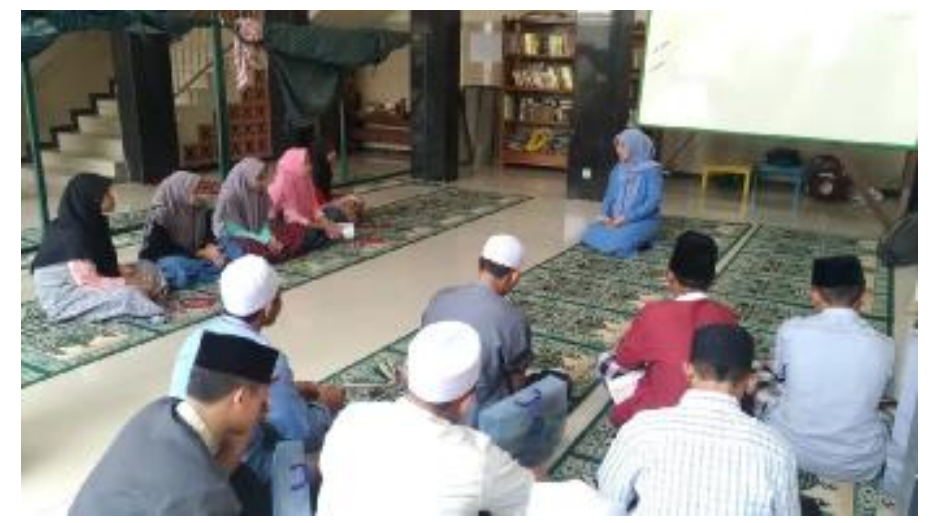

Gambar 3. Yuliana Friska, S.Pd., M.Pd. menyajikan materi di yayasan Al-kamilah

Pertemuan kedua dilakukan satu minggu kemudian setelah pertemuan pertama. Pertemuan kedua disajikan oleh Anita Anggraini, S.Pd., M.Pd. yang merupakan lulusan dari Universitas Negeri Yogjakarta. Anita Anggraini, S.Pd., M.Pd. menyajikan materi tentang matematikan sederhana, yaitu aritmatika dan geometri. Pelatihan aritmatika diutamakan tentang barisan dan deret hitung, karena ini sangat penting dan merupakan soal yang sering dikeluarkan untuk tes masuk perguruan tinggi ataupun untuk masuk kerja di berbagai perusahaan. Selain itu, Anita Anggraini, S.Pd., M.Pd. dibantu oleh Johan Syahbrudin, S.Pd., M.Pd. yang merupakan suaminya sehingga pertemuan kedua tidak monoton dan menjadi lebih menyenangkan serta membuat siswa-siswi Al-Kamilah lebih bersemangat.

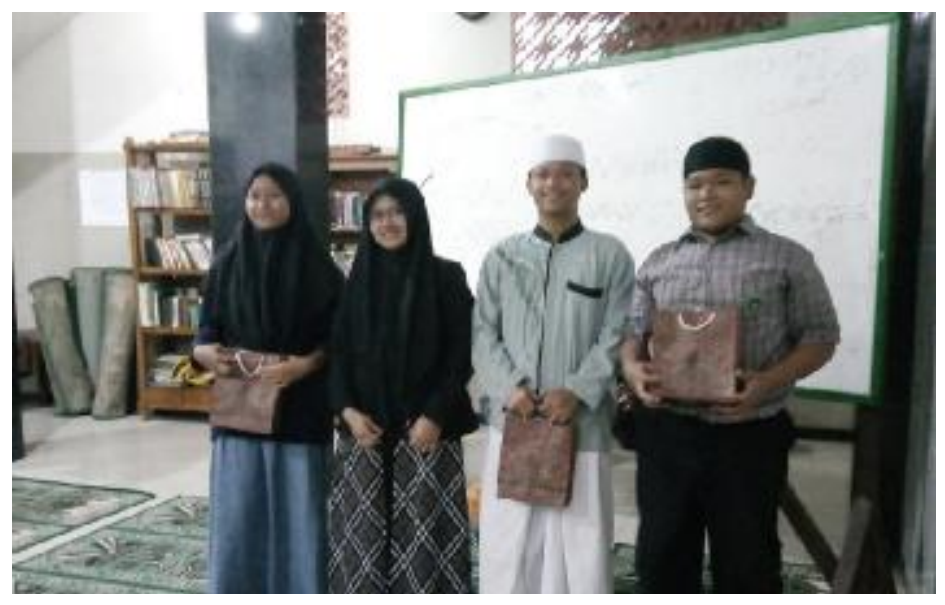

Gambar 4. Anita Anggraini, S.Pd., M.Pd. memberikan hadiah kepada para penanya

Tepat seminggu setelah Anita Anggraini, S.Pd., M.Pd. memberikan pelatihan tentang barisan dan deret hitung, Moh. Thoyib Syafi'I, S.Pd., M.Hum. yang mendapatkan gelar magister dari Universitas 
Pendidikan Indonesia menjelaskan materi praktek Bahasa Inggris sederhana berupa penggunaan waktu yang tepat dalam kalimat (tenses). Peserta pelatihan diberikan contoh-contoh dalam penggunaan kalimat sederhana, kemudian setiap peserta pelatihan diminta untuk membacanya dalam Bahasa Inggris. Ini merupakan materi yang sangat menarik karena dalam Bahasa Inggris setiap penggunaan waktu yang berbeda menjadikan kalimat berbeda structure pula. Untuk lebih menarik peserta dan menambah keaktifannya, Moh. Thoyib Syafi'I, S.Pd., M.Hum. memberikan hadiah kepada beberapa peserta pelatihan yang dapat menjawab pertanyaan dengan benar. Hal ini perlu dilakukan mengingat sebagian besar dari anak asuh yayasan Al-Kamilah merupakan siswa-siswi SD dan SMP yang masih perlu distimulasi agar mau belajar secara serius. Motivasi pemberian hadiah merupakan cara yang efektif untuk memaksimalkan konsentrasi peserta pelatihan.

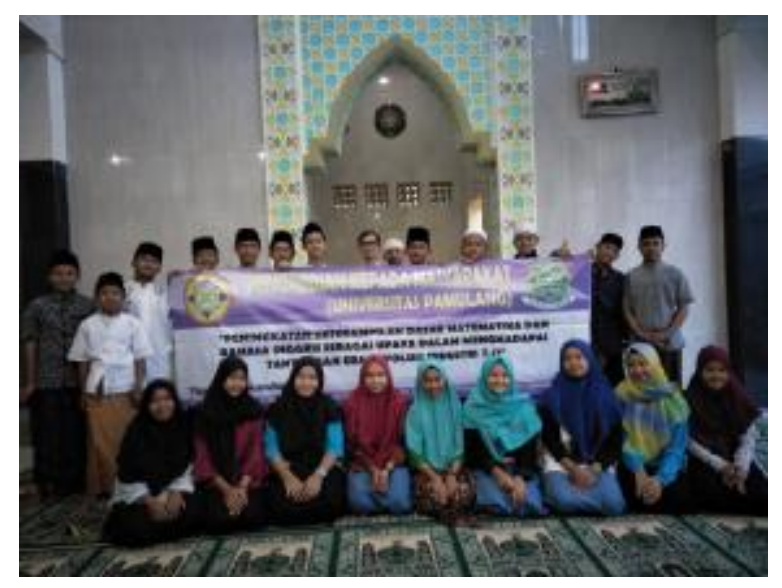

Gambar 5. Moh. Thoyib Syafi'I, S.Pd., M.Hum. berfoto bersama anak asuh Al-Kamilah

Seminggu berikutnya diisi oleh Ani Kusumaningsih, S.T., M.M. dengan memberikan materi pelatihan berbicara dalam Bahasa Inggris kembali. Ani Kusumaningsih, S.T., M.M. kembali mengajarkan Bahasa Inggris kepada peserta pelatihan dan memberikan souvenir yang disampaikan kepada pendiri yayasan Al-Kamilah sebagai tanda tali asih. Ani Kusumaningsih, S.T., M.M. merupakan dosen senior di Universitas Pamulang sehingga kemampuan mengajarnya tidak diragukan lagi. Selain itu, Ani Kusumaningsih, S.T., M.M. juga sering mendapatkan pelatihan dari Bank Permata, Standard Chartered Bank dan Astra hingga ke manca negara sehingga sudah terbiasa berinteraksi dengan penutur asing dari berbagai negara dengan beragam aksen mereka. Dengan kata lain, Ani Kusumaningsih, S.T., M.M. sudah sering melakukan komunikasi dengan rekan bisnis dari luar negeri (native speaker). Ditambah pengalaman bekerja di bank selama lebih dari 25 tahun sangat mendukung untuk memberikan materi English for Business kepada siswa-siswi Al-Kamilah. Kemampuan berupa soft skill berkomunikasi dengan native speaker ini lah yang akan ditularkan oleh narasumber agar anak asuh yayasan Al-Kamilah dapat bersaing dengan para pekerja dari negara lain di era milenial yang serba berbasis teknologi ini.

Setelah semua narasumber memberikan pelatihan matematika sederhana dan berbahasa Inggris, maka tim pengabdi memberikan kuisioner dan soal kepada peserta pelatihan sebagai tolok ukur sejauh mana materi dapat diterima serta untuk memonitor perkembangan kemampuan peserta pelatihan terhadap matematika dan Bahasa Inggris. Hasil dari pelatihan ini akan dipublikasikan dalam bentuk jurnal pengabdian kepada masyarakat. Selain publikasi jurnal, tim pengabdi juga akan membuat buku yang akan diterbitkan dengan ISBN juga akan dikirimkan kepada penerbit agar daya jangkau hasil pengabdian ini lebih tersebar luas kepada para akademisi lain dan praktisi dalam bidang pendidikan. 


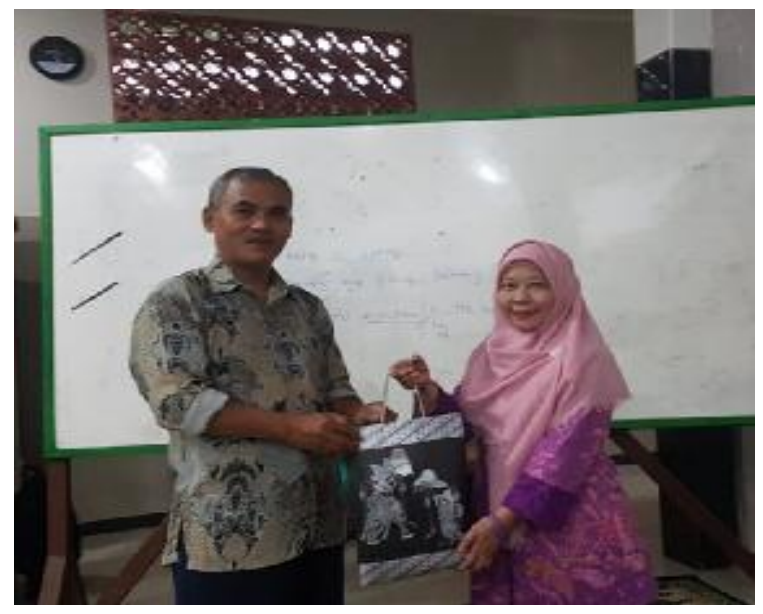

Gambar 6. Ani Kusumaningsih, S.T., M.M. memberi kenang-kenangan kepada ketua yayasan

Partisipasi mitra dalam pelaksanaan pengabdian ini sangat dibutuhkan, yaitu sebagai peserta pembelajaran/pelatihan dengan tugas-tugas di antaranya: mengikuti pembelajaran secara serius dan menyeluruh, melaksanakan tugas-tugas yang diberikan, dan bersedia memberikan umpan balik atas pelatihan yang diberikan. Dan bagi narasumber juga melakukan perencanaan pelatihan, melakukan proses pelatihan, dan mengevaluasi hasil dari pelatihan yang telah dilakukan. Hasil evaluasi tersebut dilakukan untuk mengetahui kekurangannya dan terus diperbaiki dengan process improvement (inovasi), hingga ditemukan metode yang paling efektif. Hal ini sesuai dengan prinsip ATM (Amati, Tiru, Modifikasi) atau menurut istilah bapak pendidikan kita Ki Hajar Dewantoro adalah prinsip 3N (Niteni/mengamati, Nirokake/meniru, Nambahi/menambahkan).

\section{Hasil dan Pembahasan}

Materi yang diberikan berfokus pada kemampuan siswa dalam memahami dan menguasai Matematika dan Bahasa Inggris. Dari hasil evaluasi post-test yang dilakukan tim pengabdi pada semester sebelumnya peningkatan kemampuan Matematika dan Bahasa Inggris siswa-siswi AlKamilah tidak bertambah secara signifikan. Salah satu factor penyebabnya adalah waktu yang hanya 90 menit setiap pertemuan. Oleh karena itu pada pelatihan kali ini, tim pengabdi menambahkan waktu yaitu 120 menit sekali pertemuan dengan materi yang lebih interaktif, sehingga para siswa berpartisipasi lebih aktif.

Selain itu, quiz selalu dilakukan setelah selesai materi baik dalam pelajaran Bahasa Inggris maupun Matematika berbentuk tes tulis ataupun test oral sehingga dapat dievaluasi penguasaan siswasiswi pada pelajaran Matematika dan Bahasa Inggris.

Berdasarkan table 1 dapat dilihat hasil perhitungan pre-test, post-test 1 (pkm semester sebelumnya), and post-test 2 (pkm pada semester ini) pada pelajaran Bahasa Inggris ditemukan bahwa terdapat perubahan signifikan hasil rata-rata pre-test dan post-test. Tabel di atas menunjukkan rata-rata hasil pre-test yaitu 53.00 dan hanya ada 2 orang siswa dari 15 orang yang mendapat nilai 70. Selain itu, berdasarkan hasil evaluasi post-test yang dilakukan tim pengabdi pada semester sebelumnya peningkatan kemampuan Matematika dan Bahasa Inggris siswa-siswi Al-Kamilah tidak bertambah secara signifikan. Hal tersebut dapat dilihat pada table post-test (1) di atas yang menunjukkan peningkatan rata-rata hasil pelatihan selama 1 semester menjadi 63.33 dan siswa yang mendapat nilai 
70 /ebih dari 70 bertambah menjadi 5 orang. Hal ini membuktikan bahawa peningkatan hasil pelatihan selama 1 semester dibawah 50\% sehingga tim pengabdi menyimpulkan bahwa hasil dari pengabdian pada semester sebelumnya tidak signifikan. Berdasarkan skor terhadap hasil post-test, tim pengabdi mendapatkan hasil bahwa tidak terdapat perubahan signifikan antara hasil mean pre-test dan post-test hasil belajar Matematika maupun Bahasa Inggris. Sedangkan untuk pemahaman perihal revolusi industri 5.0 mengalami perubahan signifikan. Sebelum diberikan perlakuan pelatihan, siswa/siswi yayasan Al-Kamilah tidak mengetahui banyak perihal era revolusi industri 5.0. Namun hasil yang berbeda terjadi setelah diberikan tindakan pelatihan selama 1 bulan.

Tabel 1. Nilai Bahasa Inggris siswa-siswi Al-Kamilah

\begin{tabular}{cccc}
\hline Responden & PRETEST & POSTTEST (1) & POSTTEST (2) \\
\hline 1 & 45 & 60 & $75^{*}$ \\
\hline 2 & 55 & 65 & $75^{*}$ \\
\hline 3 & 65 & $75^{*}$ & $75^{*}$ \\
\hline 4 & 55 & 60 & $80^{*}$ \\
\hline 5 & $70^{*}$ & $75^{*}$ & $75^{*}$ \\
\hline 6 & 50 & $70^{*}$ & $75^{*}$ \\
\hline 7 & 55 & 65 & $85^{*}$ \\
\hline 8 & $70^{*}$ & $75^{*}$ & $75^{*}$ \\
\hline 9 & 40 & 55 & $75^{*}$ \\
\hline 10 & 50 & 55 & $75^{*}$ \\
\hline 11 & 55 & $70^{*}$ & $75^{*}$ \\
\hline 12 & 45 & 55 & $70^{*}$ \\
\hline 13 & 35 & 50 & $75^{*}$ \\
\hline 14 & 55 & 60 & $75^{*}$ \\
\hline 15 & 50 & 60 & 76.00 \\
\hline Skor Rerata & 53.00 & 63.33 & \\
\hline
\end{tabular}

Dengan kata lain, pelatihan Matematika dasar dan Bahasa Inggris perlu diadakan lebih lama lagi agar memiliki dampak lebih mendalam bagi siswa/siswi yayasan Al-Kamilah. Hal ini terjadi karena kemampuan awal yang dimiliki siswa/siswi Al-Kamilah masih jauh dari kemampuan rata-rata siswa seangakatannya. Selain itu, dosen tim pengabdi hanya mampu mengajar selama 1,5 jam dalam 1 minggu. Hal ini terjadi karena baik siswa/siswi yayasan Al-Kamilah maupun dosen Universitas Pamulang memiliki jadwal dan kesibukan yang sangat padat. Hal inilah yang membuat tim pengabdi mengadakan pelatihan kembali dengan menambahkan waktu dari 1.5 jam menjadi 2 jam setiap pertemuan, sehingga didapatkan hasil yang signifikan seperti yang dapat dilihat pada table di atas. Hasil rata-rata post-test (2) meningkat dari 63.33 menjadi 76.00 dan semua siswa mendapat nilai lebih dari 70, sehingga dapat disimpulkan bahwa terdapat peningkatan signifikan terhadap hasil pelatihan pada semester ini. Selain itu, anak-anak asuh Al-Kamilah sangat antusias mengimplementasikan pelajaran yang dipelajari dengan cara menggunakan Bahasa Inggris ketika mengajukan pertanyaan saat proses belajar mengajar berlangsung. Hal ini membuktikan bahwa terdapat perubahan positif dalam penguasaan Bahasa Inggris siswa $/$ Yayasan Al-Kamilah setelah diberikan pelatihan berkelanjutan dari program pelatihan semester sebelumnya,

Begitupula dengan pelajaran Matematika. Terdapat peningkatan hasil post-tes siswa/ AlKamilah dibandingkan dengan hasil post-tes pada pelatihan semester sebelumnya setelah dilakukan penambahan waktu belajar. Siswa $\mathbb{\Lambda}$ juga lebih aktif bertanya pada saat proses belajar mengajar. Selain 
itu, anak-anak asuh Al-Kamilah dapat menjawab quiz yang diberikan dalam bentuk oral tes dengan antusias.

Selain itu, siswa-siswi Alkamilah juga berprestasi di bidang lain, yaitu salah satunya adalah hadroh. Yayasan Al-kamilah merupakan yayasan teladan sehingga memberikan pelatihan secara meluas kepada anak didiknya. Anak didik di Yayasan Al-kamilah memiliki jadwal yang padat.

Hal ini merupakan kesempatan berbagi sekaligus beramal tim pengabdi di Yayasan Al-Kamilah. Selain itu, sisi positif yang juga didapat dari pelatihan yang sudah diadakan selama 1 bulan, yaitu kemampuan siswa/siswi yayasan Al-Kamilah yang sangat cepat menerima pelajaran dapat meningkat secara signifikan. Dengan demikian, logika berpikir mereka sudah mulai terasah dan dengan memberikan pelatihan kembali secara berkelanjutan diharapkan memberikan hasil positif dan dapat membantu siswa-siswi Al-Kamilah meningkatkan kemampuan akademiknya di sekolah terutama pada pelajaran matematika dan Bahasa Inggris.

\section{Kesimpulan}

Dengan pelatihan kemampuan dasar Matematika dan Bahasa Inggris selama rentang waktu 1 bulan belum memberikan perubahan pada nilai rata-rata hasil belajar post-test sehingga diperlukan pelatihan lebih lama agar hasil belajar berubah sesuai hasil yang diharapkan tim pengabdi.

\section{Ucapan Terimakasih}

Terimakasih yang sebesar-besarnya kami tujukan kepada pengurus dan adik-adik di Yayasan AlKamilah khususnya yang berlokasi di Jl. Serua Raya No 3, Serua, Kec. Bojongsari, Kota Depok yang telah menyambut tim pengabdi dengan sangat baik dan bersedia meluangkan waktunya selama kegiatan.

\section{Daftar Pustaka}

Abramovich, S. (2014). Revisiting mathematical problem solving and posing in the digital era: toward pedagogically sound uses of modern technology. International Journal of Mathematical Education in Science and Technology, 45(7), 1034-1052. https://doi.org/10.1080/0020739X.2014.902134

Hidayat, A. (2019). Student's Self-Concept Profiles In Problem Posing According To Cognitive Styles: Developing An Evidence Base For Best Practice Of E-Learning In Mathematical Economics Course At Pamulang University. Jurnal Saintika Unpam: Jurnal Sains Dan Matematika Unpam, 1(2), 158-165.

Hidayat, A., Friska, Y., Anggraini, A., Syafi'i, M. T., \& Kusumaningsing, A. (2019). Peningkatan Keterampilan Dasar Matematika dan Bahasa Inggris Sebagai Upaya Dalam Menghadapi Tantangan Era Revolusi Industri 5.0. ABDIMISI, 1(1), 55-62.

Hidayat, A., \& Prasetya, E. R. (2020). Penerapan Teknologi Dalam Analisis Perilaku Belajar Reflektif Berbasis Sistem Android Untuk Meningkatkan Pembelajaran E-Learning. Gammath: Jurnal Ilmiah Program Studi Pendidikan Matematika, 4(2), 79-87. 
Kariadinata, R. (2012). Menumbuhkan Daya Nalar ( Power of Reason ) Siswa Melalui Pembelajaran Analogi Matematika. Infinity Journal, 1(1), 10-18. https://doi.org/10.22460/infinity.v1i1.3

Ku, O., Chen, S. Y., Wu, D. H., Lao, A. C. C., Chan, T., Ku, O., Chen, S. Y., Wu, D. H., Lao, A. C. C., \& Chan, T. (2014). International Forum of Educational Technology \& Society The Effects of GameBased Learning on Mathematical Confidence and Performance: High Ability vs . Low Ability Published by: International Forum of Educational Technology \& Society Linked references . Journal of Educational Technology $\mathcal{E} \quad$ Society, $17(3), \quad 65-78$. http://search.ebscohost.com/login.aspx?direct=true\&AuthType=ip,url,uid\&db=eue\&AN=98543290 \&lang $=$ it\&site=ehost-live

Pujiono, S. (2012). Berpikir Kritis dalam Literasi Membaca dan Menulis untuk Memperkuat Jati Diri Bangsa. Prosiding PIBSI XXXIV, 778-783.

Wahyuni, S., Indriastuti, N. R., \& Mustikawati, D. A. (2018). The Implementation of Picture Series to Improve Students Speaking Ability at The Second Grade of SMP Muhammadiyah 3 Jetis Ponorogo in Academic Year 2016/2017. EDUPEDIA, 2(2), 148-160. 